\title{
Enhancing Rice Productivity in the Unfavourable Ecosystems of Bangladesh
}

\author{
MS Rahman ${ }^{*}$, M M Haque ${ }^{2}$, M J Kabir ${ }^{3}$, A K MS Islam4, M A R Sarkar³, M A A Mamun5, M U Salam \\ and MS Kabir ${ }^{7}$
}

\begin{abstract}
Rice is cultivated in the three seasons (Aus, Aman, and Boro) across four ecotypes, including irrigated, rainfed upland, rainfed lowland, and deep water in Bangladesh. Rice farming in unfavourable ecosystems is highly exposed to abiotic stresses and extreme weather events (floods, droughts, storm surges, and cyclones), and its performance is frequently affected by the multiple-stresses and extreme weather events. Besides, the increasing demand for rice for the growing population and decreasing scarce resources, including arable land and fresh-water for irrigation aggravated the concern about sustainable rice production systems under future conditions. Thus, the paper aimed to exploit unfavourable ecosystems to increase total rice production for meeting future demand. Secondary data were analyzed to achieve the objectives of the study. BR23, BRRI dhan40, BRRI dhan41, BRRI dhan47, BRRI dhan53, BRRI dhan54, BRRI dhan61, BRRI dhan67, BRRI dhan73, BRRI dhan97, BRRI dhan99, BINA dhan-8 and BINA dhan-10 are resilient to salinity. Besides, BRRI dhan56, BRRI dhan57, BRRI dhan66, BRRI dhan71, and BRRI dhan83 are resilient to drought, and BRRI dhan51, BRRI dhan52, BRRI dhan79, BINA dhan11, and BINA dhan-12 are tolerant to submergence. The BR18, BRRI dhan36, BRRI dhan67, and BRRI dhan69 are some-extent resilient to cold. The research has been continuing for developing further stress-tolerant higher yield potential rice cultivars for unfavourable ecosystems. The increased adoption of currently available stress-tolerant rice cultivars has the potential to give a substantially higher yield than that of locally popular rice cultivars in the unfavourable ecosystems. Therefore, the dissemination of stress-tolerant cultivars to $75 \%$ of total rice cropping areas of saline (0.37 Mha), submergence (1.08 Mha), and drought (2.94 Mha) ecosystem may contribute to increasing rice production in the ecosystems by $1.26 \mathrm{MT}, 3.45 \mathrm{MT}$, and $9.18 \mathrm{MT}$, respectively. Resulting from that $13.89 \mathrm{MT}$ rice will be added to the national rice basket in 2050 . The policy supports are needed to strengthen for developing and rapid dissemination of the stress-tolerant cultivars in the unfavourable ecosystems for meeting the increased demand of rice of the growing population under future conditions.
\end{abstract}

Key words: Rice, unfavourable ecosystem, salinity, submergence, drought, climate change.

\section{INTRODUCTION}

Bangladesh is a low lying agrarian country. The land surface of the country is mostly floodplain $(80 \%)$, a few areas under terraces $(8 \%)$, and hills (12\%) (FAO, 1988). Besides, the country belongs to a favourable environment for growing rice across the year in the three overlapping seasons (Aus, Aman, and Boro) and four ecotypes included irrigated, rainfed upland, rainfed lowland, and deep water. Boro rice is a photoperiod insensitive irrigated rice grown in the dry season (DS: DecemberMarch). Aus rice is also photoperiod insensitive and mostly grown in rainfed conditions in the early wet season. Transplanted Aman is a mostly photoperiod sensitive rice grown in the wet season under rainfed conditions (Uddin, 1993). However, rice farming in the country, in particular in unfavourable ecosystems is frequently affected by abiotic and biotic stresses, including global warming lead extreme weather events (drought, floods, tidal surge, and cyclones). The abiotic stress in particular (i) salinity in the coastal region, (ii) submergence in the lowlying and basin areas, and (iii) tidal submergence in the non-saline coastal region, prevails in the country. Besides, drought in the

1Plant Physiology Division, Bangladesh Rice Research Institute (BRRI), Gazipur-1701, Bangladesh; 2Soil Science Division, BRRI, Gazipur-1701, Bangladesh; ${ }^{3}$ Agricultural Economics Division, BRRI, Gazipur-1701, Bangladesh; 4 Farm Machinery and Postharvest Technology Division, BRRI, Gazipur-1701, Bangladesh; ${ }^{5}$ Agricultural Statistics Division, BRRI, Gazipur-1701, Bangladesh; ${ }^{6}$ Freelance International Consultant (Agricultural Systems), Bangladesh; 'Director General, BRRI, Gazipur-1701, Bangladesh.

*Corresponding author's E-mail: sazzadur.phys@brri.gov.bd (M S Rahman) 
dry season, early wet season (EWS: April-June) and wet seasons (WS: July-September), and cold in the Boro season in the north-west and north-east (Haor) regions also prevails. The arable area under drought-prone ecosystem (4.20 M ha) was higher followed by rainfed low land (3.20 M ha), submergence $(2.80 \mathrm{M}$ ha), and salinity (1.2 M ha) (Table 1 ). Besides, the country was affected by over 200 extreme weather events across the last two decades, consequently per year economic loss of the country was about $1 \%$ of total national GDP (Kreft et al., 2016).

Although a bulk of studies were carried out for assessing the impact of climate and environmental change on the performance of rice and non-rice crop farming ( $\mathrm{Yu}$ et al., 2010; Ruane et al., 2013; Thurlow et al., 2012; Kabir et al., 2018a) and farmers adaptation to climate change (Kabir et al., 2016; Kabir et al., 2017a; Kabir et al., 2017b; Kabir et al., 2017c; Kabir et al., 2018b; Kabir et al., 2019; Kabir et al., 2020) in Bangladesh, in particular in the stress ecosystem. However, none of the studies found to explore the potential of the unfavourable ecosystems to contribute to the national rice basket under future conditions
(2030, 2040 and 2050). Thus, the paper explores the prospects and potential for increasing and sustaining rice productivity in unfavourable ecosystems.

\section{METHODOLOGY}

The data were collected from different published and unpublished secondary sources, including journal articles, reports, and presentations of BRRI (Bangladesh Rice Research Institute), BARI (Bangladesh Agricultural Research Institute), BINA (Bangladesh Institute of Nuclear Agriculture), IRRI (International Rice Research Institute), SRDI (Soil Resource Development Institute), FAO (Food and Agriculture Organization of the United Nations). The adoption of stresstolerant rice cultivars and their potential performance in the saline, drought, and submergence ecosystems under future conditions was extrapolated based on(i) current adoption status of stress-tolerant cultivars and (ii) potentiality of currently available stress-tolerant cultivars for those ecosystems. Besides, the potentiality of enhancing rice production in the other ecosystems, including tidal non-saline, haor, rainfed lowland, upland, and Charland.

Table 1. Arable area under unfavourable ecosystems in Bangladesh.

\begin{tabular}{llc}
\hline Ecosystem & Existence of other stress & Area (M ha) \\
\hline Salinity & $\begin{array}{l}\text { Tidal submergence in wet season, Heat and drought stress at reproduc- } \\
\text { tive phase of Boro rice }\end{array}$ & 1.20 \\
Flash flood (submergence) & Flash flooding at vegetative phase of T. Aman rice & 2.00 \\
Tidal submergence & Heavy siltation and turbulence & 0.80 \\
Haor (Deepwater rice) & Drought at vegetative phase & 0.80 \\
Drought & Heat at reproductive phase & 4.20 \\
Rainfed lowland & $\begin{array}{l}\text { Flood and water stagnation at vegetative phase and drought at repro- } \\
\text { ductive phase }\end{array}$ & 3.20 \\
Upland & Drought at vegetative phase and heat stress at reproductive phase & 0.20 \\
Charland & $\begin{array}{l}\text { Drought and submergence at vegetative phase and heat stress at repro- } \\
\text { ductive phase }\end{array}$ & 0.83 \\
Low temperature\# & $\begin{array}{l}\text { Cold at seedling stage of Boro rice at North-East and North-West region } \\
\text { and reproductive phase of Boro rice at North-East region (Haor) }\end{array}$ & 2.00 \\
High temperature \# & $\begin{array}{l}\text { Heat at flowering stage of long duration Boro, Upland Aus and short } \\
\text { duration T. Aman }\end{array}$ & -- \\
\hline
\end{tabular}

${ }^{*} \mathrm{M}$ ha= Million hectare; Area adapted from Kabir et al., 2018c; \#This is not an ecosystem rather stress condition.

84 Rahman et al. 


\section{RESULTS AND DISCUSSION}

This section presents the status of currently available rice technologies for unfavourable ecosystems. Thereafter, constraints of rice farming and the necessities for improvement of the technologies for those ecosystems were presented. Besides, the extrapolated potential contribution of saline, submergence, and drought ecosystem in 2030, 2040 and 2050 in Bangladesh was also presented in the section.

\section{Status of rice cultivars for unfavourable eco- system}

Table 2 presents the progress in rice breeding in developing cultivars for unfavourable ecosystems in Bangladesh.

Bangladesh Rice Research Institute (BRRI) and Bangladesh Institute of Nuclear Agriculture (BINA) have developed about 33\% variety for stress ecosystems (Salam et al., 2019). Most of them are higher yield potential and stressresilient rice cultivars such as BR23, BRRI dhan40, BRRI dhan41, BRRI dhan47, BRRI dhan53, BRRI dhan54, BRRI dhan61, BRRI dhan67, BRRI dhan73, BRRI dhan97, BRRI dhan99, BINA dhan8 and BINA dhan10 for saline ecosystem. Besides, BRRI has developed BRRI dhan56, BRRI dhan57, BRRI dhan66, BRRI dhan71, and BRRI dhan83 for the draught ecosystem. BRRI dhan51, BRRI dhan52, BRRI dhan79, BINA dhan11, and BINA dhan12 were released for submergence ecosystem. BR18, BRRI dhan36, BRRI dhan67, and BRRI dhan69 are some-extent resilient to cold. Large-scale dissemination of the cultivar potential to enhance rice production for ensuring rice security and increasing farm income is needed in the fragile ecosystems (Table 2).

\section{Saline ecosystem}

The region consists of 147 upazilas of 19 districts covering about $32 \%$ of total areas of the country (BBS, 2018) of which 48 upazilas of 12 districts are directly exposed to the Bay of Bengal. The exposed coastal districts are highly vulnerable to salinity intrusion and extreme weather events (Bala and Hossain, 2010).

Table 2. Progress in rice breeding in developing cultivars for unfavourable ecosystems in Bangladesh.

\begin{tabular}{|c|c|}
\hline Unfavourable ecosystem & Rice cultivars for unfavourable ecosystems* \\
\hline Salinity & $\begin{array}{l}\text { BRRI dhan47, BRRI dhan61, BRRI dhan67, BRRI dhan97, BRRI dhan99, BINA } \\
\text { dhan8, BINA dhan10 for Boro season. BR23, BRRI dhan40, BRRI dhan41, BRRI } \\
\text { dhan53, BRRI dhan54, BRRI dhan73, BRRI dhan78 for T. Aman season }\end{array}$ \\
\hline Flash flood submergence & BRRI dhan51, BRRI dhan52, BRRI dhan79, BINA dhan11, BINA dhan12 \\
\hline Tidal submergence & BRRI dhan44, BRRI dhan76 and BRRI dhan77 for non-saline condition \\
\hline Haor (Medium deep area) & BRRI dhan91 \\
\hline Drought & BRRI dhan56, BRRI dhan57, BRRI dhan66 and BRRI dhan71 \\
\hline Rainfed lowland & $\begin{array}{l}\text { BR10, BR11, BR22, BR23, BR25, BRRI dhan30, BRRI dhan31, BRRI dhan32, BRRI } \\
\text { dhan46, BRRI dhan49, BRRI dhan72, BRRI dhan75, BRRI dhan87 }\end{array}$ \\
\hline Upland & $\begin{array}{l}\text { BR21, BR24, BRRI dhan27, BRRI dhan42, BRRI dhan43, BRRI dhan65, BRRI } \\
\text { dhan83 (for B. Aus) and BRRI dhan26, BRRI dhan } 48 \text {, BRRI dhan55, BRRI } \\
\text { dhan82, BRRI dhan } 85 \text { and BRRI dhan } 98 \text { (for T. Aus) }\end{array}$ \\
\hline Charland & All drought tolerant, short duration and submergence tolerant varieties \\
\hline Low temperature (Cold stress)\# & $\begin{array}{l}\text { BR18 and BRRI dhan36 (tolerant at seedling stage); BRRI dhan } 67 \text { and BRRI } \\
\text { dhan } 69 \text { is tolerant at reproductive phase }\end{array}$ \\
\hline High temperature (Heat stress) ${ }^{\#}$ & BRRI dhan62 is moderate tolerant at flowering stage \\
\hline
\end{tabular}


The Soil Resource Development Institute (SRDI) reported about 1.056 million ha arable areas affected by different degrees of salinity in 2009 from only about 0.833 in 1973 . The salinity affected area increased by $26 \%$ over the last four decades (1973-2009) (SRDI, 2010).

The slightly (4.1-8.0 $\left.\mathrm{dS} \mathrm{m}^{-1}\right)$ saline affected area decreased by 153,000 ha during 1973-2009. However, moderate strong (8.1-12.0 dS $\left.\mathrm{m}^{-1}\right)$ to strong (12.1-16.0 dS $\left.\mathrm{m}^{-1}\right)$ and very strong $(>16.0$ dS $\mathrm{m}^{-1}$ ) salinity affected area increased by 272,000 ha and 62,000 ha, respectively during 1973-2009. Besides, low to very slight $(2.0-4.0$ $\mathrm{dS} \mathrm{m}^{-1}$ ) salinity affected area increased by 41,000 ha during 1973-2000. The salinity intrusion dynamics in the arable area indicate that soil salinity in the arable area in Bangladesh has been increasing both vertically and horizontally over time (1973-2009) (Table 3). Despite the environmental limitation, the coastal region contributes about $25 \%$ of total rice production to the national rice basket from about $28 \%$ of the total cultivable land of the country (BBS, 2019).

\section{Constraints of cropping for saline ecosystem}

The soil salinity and lack of fresh-water for irrigation are the first and foremost constraints for increasing crop production in coastal areas through introducing rice and non-rice crops in the dry and early wet season (Kabir et al., 2016; Kabir et al., 2019). Besides, extreme weather events, in particular, drought and heat drove moisture stress, and torrential rain-driven water stagnation from dry to early wet season substantially affected the performance of rice crops in the region (Kabir et al., 2016; Kabir et al., 2019). However, Aus and Boro rice are more resilient to those extreme weather events than non-rice crops (Moniruzzaman et al., 2020). Moreover, tidal surge, storms, and depression driven torrential rain frequently affected crops farming and livelihoods across the years. Furthermore, excess moisture in the soil is also a constraint for timely sowing non-rice dry season crops in coastal regions (Kabir et al., 2016; Kabir et al., 2019). Finally, blockage drainage canals and tidal flooding in the lowlying areas limit the potential for non-rice cropping in the areas of the coastal region.

The rice is saline sensitive crop and the yield of sensitive cultivars decreased by $12 \%$ in the soil having salinity over $3 \mathrm{dS} \mathrm{m}^{-1}$ (Mass and Hoffman, 1977). The yield of sensitive cultivars decreased by $50 \%$ in the soil with salinity $6 \mathrm{dS} \mathrm{m} \mathrm{m}^{-1}$. Besides, even the yield of saline tolerant cultivars reduced by $35-40 \%$ in the soil with $12.5 \mathrm{dS} \mathrm{m}^{-1}$ salinity compared to nonsaline soil (Rana, 1985). However, the development of saline tolerant crop cultivars is difficult due to the dynamic nature of salt stress and a broader range of plant responses to salinity at different growth stages (Munns and Tester, 2008).

Due to the above-mentioned constraints, fallow in the dry season followed by fallow in the early wet season and rice in the wet season is the most dominant cropping pattern in the coastal region. This followed by rice in the dry season followed by fallow in the early wet season and rice in the wet season is the second most dominant cropping pattern in the coastal

Table 3. Status of salinity affected areas in the coastal Bangladesh.

\begin{tabular}{cccccc}
\hline \multirow{2}{*}{ Year } & \multicolumn{5}{c}{ Salinity class and level $\left(\mathrm{dS} \mathrm{m}^{-1}\right)$ and area $\left(000^{\prime}\right.$ ha $)$} \\
& S1: $2-4$ & S2: $4.1-8$ & S3* $^{*}: 1-16$ & S4: $>16$ & All \\
\hline 1973 & 287.37 & 426.43 & 79.75 & 39.90 & 833.45 \\
2000 & 289.76 & 307.20 & 336.58 & 87.14 & 1020.80 \\
2009 & 328.43 & 274.22 & 351.69 & 101.92 & 1056.30 \\
\hline
\end{tabular}

Source: Adapted from SRDI, 2010, *S3 = S3 + S4 (8.1-12 to 12.1-16.0 $\left.\mathrm{dSm}^{-1}\right)$, S1 $\left(2-4 \mathrm{dS} \mathrm{m}^{-1}\right)=$ Non saline to very slightly saline, S2 (4.1-8 $\left.\mathrm{dS} \mathrm{m}^{-1}\right)=$ Very slightly to slightly saline, S3 $\left(8.1-12 \mathrm{dS} \mathrm{m}^{-1}\right)=$ Slightly to moderately saline, S4 (12.1-16 dS $\left.\mathrm{m}^{-1}\right)=$ Moderately to strong saline and S5 $\left(>16 \mathrm{dS} \mathrm{m}^{-1}\right)=$ Strongly to very strong saline 
region (Rashid et al., 2017 and Ibrahim et al., 2017). The cropping intensity $(159 \%)$ is largely lower than the national average cropping intensity $(197 \%)$ in the country. Besides, per hectare yield of rice in the Aus $\left(2.19 \mathrm{t} \mathrm{ha}^{-1}\right)$ and Aman $\left(2.28 \mathrm{t} \mathrm{ha}^{-1}\right)$ season in the coastal district was notably lower than the yield of the rice crops (Aus $2.56 \mathrm{t} \mathrm{ha}^{-1}$ and Aman 2.53t ha-1) in the favorable ecosystem. However, despite the adverse consequence of salinity, the yield of HYV Boro (3.74 $\left.\mathrm{t} \mathrm{ha}^{-1}\right)$ in the coastal district was slightly lower than the national average yield of HYV cultivars in Boro season (3.91 $\mathrm{t} \mathrm{ha}^{-1}$ ) (BBS, 2018). It may be because of the adverse consequences of salinity is offset by the $\mathrm{Na}^{+}$existed that in the coastal saline soil as the lower concentration $\left(<3 \mathrm{dS} \mathrm{m}^{-1}\right)$ of $\mathrm{Na}^{+}$is beneficial for the growth and development of plants (Idowu and Aduayi, 2007). The result indicates that there is potential for increasing crop production in particular rice production through both the horizontal (area expansion) and vertical (adoption of stress-tolerant cultivars and recommended management) approaches.

\section{Prospect and potential of rice production in saline ecosystem}

The adoption of salt tolerant T. Aman cultivars such as BR23, BRRI dhan40, BRRI dhan41, BRRI dhan53, BRRI dhan54, BRRI dhan73, and BRRI dhan78 with recommended management has the potential to give a better harvest of rainfed wet-season rice in the coastal ecosystem. Similarly, adoption of salt-tolerant Boro cultivars such as BRRI dhan47, BRRI dhan61, BRRI dhan67, BRRI dhan97, BRRI dhan99, BINA dhan8, and BINA dhan10 with recommended management practice has substantial potential to give notable yield advantage over currently popular Boro cultivars in the coastal region. It was reported that the salinity tolerant cultivars (e.g., BRRI dhan54, BRRI dhan73, BRRI dhan67, and BINA dhan10) gave a $2-14 \%$ yield advantage over locally adopted popular sensitive varieties (BR11, BRRI dhan28) at saline hotspots (4.0-10.1 dS m-1) in the Satkhira and Khulna re- gion (BBRI 2017, BRRI 2018). The overall adoption of saline tolerant varieties in the coastal region was $28 \%$ and the variety gave about a $7 \%$ yield advantage over non-saline modern cultivars (Sarkar and Bhandari, 2018).

The chemical, biological, and agronomic or combining both might reduce the reclamation time of commencing cropping in the salinity-affected arable areas (Rehman et al., 2016). Besides, the potential soil toxicity may be reduced for improving the performance of the crop in the saline ecosystem through amending gypsum and other organic and inorganic fertilizers (Rehman et al., 2016). However, the reclamation approaches are costly and time-consuming as well as mostly beyond the farmers' knowledge. Therefore, the development of saline tolerant cultivars is considered as feasible and more productive than the reclamation approaches. The currently available saline tolerant rice cultivars (Table 2.) are the potential to give expected yield in the slightly saline soil $\left(4 \mathrm{dS} \mathrm{m}^{-1}\right)$ to moderate saline soil $\left(12.0 \mathrm{dS} \mathrm{m}^{-1}\right)$ that is about $75 \%$ of the total salt-affected areas in the country (SRDI, 2010) (Table 3). Besides, despite salt sensitivity, it is feasible to grow rice instead of non-rice crops in the first reclamation soil due to its inherent potential to grow under flooded conditions, because the standing water subsides the capillary rise of salinity to affect crops (Bhumbla and Abrol, 1978).

The rice production potential of the saline ecosystem was extrapolated based on the above-discussed potential of the ecosystem for ten years' interval up to 2050 considering the baseline production in 2015 . The rice production in the saline ecosystem might increase by $11.75 \%$ by 2050 , respectively subject to the dissemination of the saline tolerant rice cultivars in $75 \%$ of total salinity affected areas up to $12 \mathrm{dS} \mathrm{m}^{-1}$ (Table 4). The contribution of the ecosystem in the national rice basket might further increase by adopting recently released 
salinity tolerant rice cultivars such as BRRI dhan97 and BRRI dhan99. It was due to the cultivars are potential to give 3.93-6.56 t ha-1 even under saline condition, increased the yield to $7.10 \mathrm{t} \mathrm{ha} \mathrm{a}^{-1}$ under non-saline condition. It is also the case that the salinity resilience of both the varieties (14-15 dS $\mathrm{m}^{-1}$ for seedling stage up to three weeks and 8-10 dS m-1 from vegetative to reproductive phase) are largely higher compared to currently popular saline tolerant BRRI dhan67 (12 dS m-1 for seedling stage up to three weeks and $8 \mathrm{dS} \mathrm{m}^{-1}$ for whole growth).

Steps need to be implemented for achieving the extrapolated target of increasing rice production

Firstly, the higher yield potential and salinity tolerance (up to $12 \mathrm{dS} \mathrm{m}^{-1}$ for whole growth period) rice cultivars need to be developed through implementing classical and biotechnological techniques and disseminated up to $75 \%$ of total salinity affected areas in Boro season in the coastal ecosystem. It can be noted that the currently available rice cultivars are tolerant of 8.0-10.0 dS m-1 salinity stress.

Secondly, access to fresh-water for irrigation needs to ensure achieving the dissemination goal of Boro rice for enhancing the rice production contribution of the ecosystem. The river water directly can be applied to Boro rice through shifted transplanting time of the rice crop early since the water salinity of some coastal rivers remains below the thresh- old tolerance of rice $\left(<4.0 \mathrm{dS} \mathrm{m}^{-1}\right)$ from midJune to mid-February. Besides, trapping river water in the drainage canals by December can be used for irrigation in the Boro rice. Moreover, improved irrigation water management techniques may help to optimize the use of scarce freshwater resources to achieve the production target.

Finally, the sensitive modern and local rice cultivars should be replaced by higher yield potential saline tolerant cultivars through strengthening extension supports in ecologically unfavourable regions.

\section{Flash flood submergence ecosystem}

Heavy rain and tidal surge caused by submergence in the low-lying areas in the wet season is a common phenomenon in Bangladesh (Dewan, 2015; Rahman and Zhang, 2016). Hydrological features including low elevation of lands, criss-cross river networks, high monsoon rainfall, and location in lowextreme of some mighty rivers of India and Himalayas make the country highly vulnerable to flooding. More than $2.5 \mathrm{M}$ ha of rice lands are exposed to floods, of which 1.0 $\mathrm{M}$ ha are highly vulnerable to flooding (FAO, 2001; Gumma et al., 2012). Every year one-fifth of the total arable lands of the country are affected by different degrees of floods. As a result, the country incurs a loss per year of about BDT 4.0 billion and $4 \%$ of total rice production (Bairagi and Bari, 2015).

Table 4. Extrapolated rice production through adoption of resilient cultivars in the coastal saline ecosystem of Bangladesh.

\begin{tabular}{|c|c|c|c|c|c|}
\hline Item & Base year (2015) & 2020 & 2030 & 2040 & 2050 \\
\hline Rice area increase ( $\mathrm{M}$ ha) compared to base year & $\begin{array}{c}0.222 \\
(28)\end{array}$ & $\begin{array}{c}0.055 \\
(7)\end{array}$ & $\begin{array}{c}0.119 \\
(15)\end{array}$ & $\begin{array}{c}0.119 \\
(15)\end{array}$ & $\begin{array}{c}0.079 \\
(10)\end{array}$ \\
\hline Rice production increase (MT) compared to base year & $\begin{array}{l}0.601 \\
(7.00)\end{array}$ & $\begin{array}{l}0.161 \\
(1.75)\end{array}$ & $\begin{array}{l}0.380 \\
(3.75)\end{array}$ & $\begin{array}{l}0.416 \\
(3.75)\end{array}$ & $\begin{array}{l}0.301 \\
(2.50)\end{array}$ \\
\hline Projected yield increase over base year $\left(\mathrm{t} \mathrm{ha}{ }^{-1}\right)$ & 2.71 & 2.90 & 3.20 & 3.50 & 3.80 \\
\hline
\end{tabular}

Note: $50 \%$ of potential yield at non-saline condition was considered for estimating the yield of rice cultivars under moderate saline ( 8.1 to $\left.12.0 \mathrm{dS} \mathrm{m}^{-1}\right)$ environment. Values in the parentheses are the percentage computed based on the year 2015. 
Flash floods frequently affect rainfed lowland rice (RLR) habitats even in the early monsoon to post-monsoon, and the flood prolongs from 2-4 weeks in many areas of the country. Besides, moisture stress (drought) frequently affected the performance of T. Aman rice, in particular in the region of the north-west floods due to decrease rainfall in the postmonsoon months. Currently available submergence tolerant rice cultivars includingBRRI dhan51, BRRI dhan52, BRRI dhan79, BINA dhan11, and BINA dhan12 are tolerant to 2-3 weeks of flash flood submergence at the vegetative phase. Bairagi et al. (2018) reported that about $40 \%$ of total farm households in the flood-prone areas of north-west Bangladesh adopted the submergence tolerant rice varieties. It was reported that the submergence tolerant cultivars (e.g., BRRI dhan51, BRRI dhan52) produced a 2-14\%yield advantage over locally adopted popular submergence sensitive varieties (BRRI dhan44) in Rangpur and Lalmonirhat (BBRI 2017, BRRI 2018). Similarly reported that the submergence tolerant cultivars in the region produced a 1-4 $\mathrm{t} \mathrm{ha}^{-1}$ yield advantage over other modern cultivars (Bairagi et al., 2018). Besides, BRRI dhan51, BRRI dhan52, BINA dhan11, and BINA dhan12 produced 2-3 t ha-1 yield advantage over popular sensitive modern varieties under severe flooding conditions in Rangpur and Lalmonirhat (BRRI, 2017; BRRI, 2018). The adoption of the submergence tolerant varieties, including
BRRI dhan51, BRRI dhan52, BINA dhan11, and BINA dhan 12 was $21 \%$ of the total rice area of the ecosystem and the varieties gave a $6 \%$ yield advantage over sensitive modern cultivars (Sarkar and Bhandari, 2018). Therefore, multi-stress tolerance, including submergence and drought is required to combat the increased extreme weather events in future climates. Therefore, the tolerance of the rice cultivars should be increased up to four weeks and recurrent submergence at the vegetative phase, and drought at the reproductive phase. Besides, agronomic management needs to be improved to achieve the yield benefit. Total rice production of the submergence ecosystem was extrapolated based on the above discussed current performance of the rice varieties in the ecosystem. Total rice production in the ecosystem might increase by $15.43 \%$ subject to discrimination the submergence tolerant rice cultivars up to $75 \%$ of total rice cropping area in the ecosystem (Table 5).

\section{Drought ecosystem}

Drought is an environment caused by a lack of precipitation and high temperature for a period. The drought-driven moisture stress adversely impacts on plants, animals, and humans (Warwick, 1975). Although drought is classified as (i) meteorological, hydrological, (iii) agricultural, and socioeconomic, they are highly interlinked with each other. The number of days with less with each other. The number of days with less

Table 5. Extrapolated rice production through adoption of resilient cultivars in the submergence ecosystem of Bangladesh

\begin{tabular}{|c|c|c|c|c|c|}
\hline Item & Base year (2015) & 2020 & 2030 & 2040 & 2050 \\
\hline Rice area increase (Mha) compared to base year & $0.42(21)$ & $0.28(14)$ & $0.30(15)$ & $0.30(15)$ & $0.20(10)$ \\
\hline $\begin{array}{l}\text { Rice production increase (MT) compared to } \\
\text { base year }\end{array}$ & $0.974(6.00)$ & $\begin{array}{l}0.700 \\
(4.00)\end{array}$ & $\begin{array}{l}0.900 \\
(4.29)\end{array}$ & $\begin{array}{l}1.050 \\
(4.29)\end{array}$ & $\begin{array}{l}0.800 \\
(2.86)\end{array}$ \\
\hline Projected yield increases over base year $\left(t\right.$ ha $\left.^{-1}\right)$ & 2.32 & 2.50 & 3.00 & 3.50 & 4.00 \\
\hline
\end{tabular}

Note: Value in the parentheses is the percentage computed based on the year 2015. 
precipitation than some specified threshold is called the meteorological drought. The effect of precipitation for a period on surface or subsurface water supply in the reservoir, lake levels, and groundwater is called hydrological. The moisture deficiency at topsoil and sub-soil caused by meteorological or hydrological drought is called agriculture drought. Therefore, the crop is susceptible to agricultural drought from emergence to maturity. The supply and demand of some economic good with elements of meteorological, hydrological, and agricultural drought are called socioeconomic drought (Wilhite and Glantz,1985). Flow diagram 1 shows the drought series and impacts for generally recognized forms of drought.

The water demand of plants depends on the prevailing weather conditions, the specific plant's biological characteristics, its growth stage, and the physical as well as biological properties of the soil. Water, more than any other factor, is controlling rice growth and development at crucial stages of growth. The crop's ability to withstand drought is necessary for most areas of tropical and subtropical rice cultivation. Therefore, farmers need drought-tolerant varieties for the dryland.

Over 4.2 M ha of rainfed early wet season (Aus) and wet season (Aman) rice area is frequently affected by drought in Bangladesh. The rainfed wet-season rice in the country, particularly in the north-west drought ecosystem is frequently affected by moisture at the reproductive phase due to decrease rainfall in the post-monsoon months (Kabir et al., 2017c).

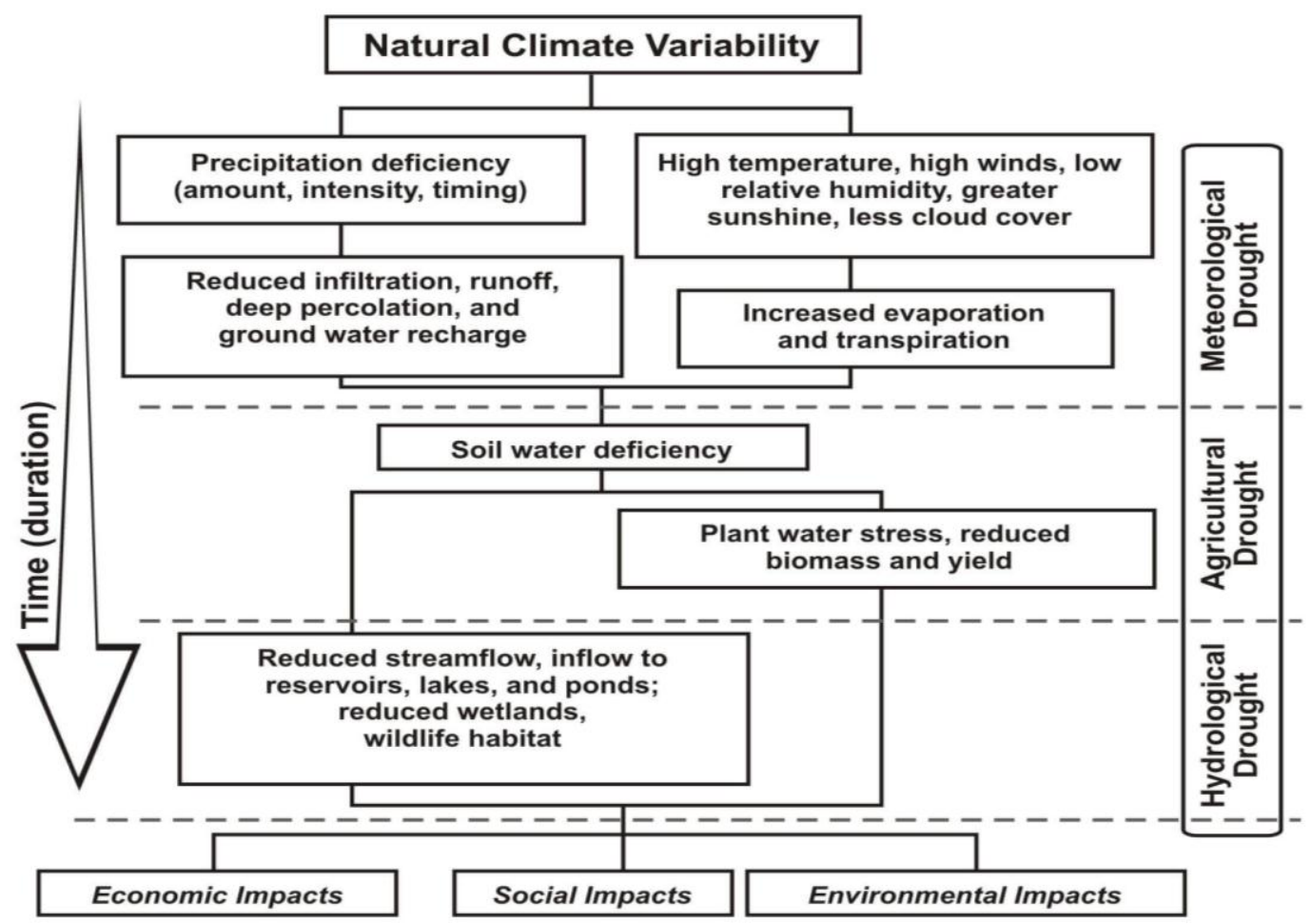

Flow diagram 1. Sequence of drought occurrence and impacts for commonly accepted drought types (adapted from National Drought Mitigation Center (NDMC):https://drought.unl.Edu/Education/Droughtlndepth/TypesofDrought.aspx/). 
Besides, the delay sowing broadcast Aman rice in the deepwater ecosystem is also affected by drought due to early withdrawal of rainfall. Therefore, the development of droughttolerant rice cultivars is a demand for changing climate conditions.

BRRI has developed some drought tolerant and drought escaping rice cultivars, such as BRRI dhan56, BRRI dan57, BRRI dhan66, BRRI dhan71, and BRRI dhan83 for Aus and Aman season to reduce unexpected yield loss due to moisture stress driven by lack of rainfall or drought. It was reported that the droughttolerant cultivars (e.g., BRRI dhan56, BRRI dhan57) produced a $6-12 \%$ yield advantage over locally adopted popular sensitive varieties (BRRI dhan49 and BINA dhan7) in Rangpur, Nilphamari, Lalmonirhat and Kurigram (BBRI, 2013). Similarly, reported that the current adoption of drought-tolerant cultivars was $5 \%$ of the total rice area in the ecosystem, and the variety produced a $1.5 \%$ yield advantage over sensitive varieties (Sarkar and Bhandari, 2018). Total rice production of the drought ecosystem was extrapolated based on the above discussed current performance of the rice varieties in the ecosystem. Total rice production in the ecosystem might increase by $21 \%$ subject to the dissemination of the drought-tolerant and escaping rice cultivars up to $75 \%$ of the total rice cropping area in the ecosystem (Table 6). It can be noted that further moisture stress-tolerant cultivars need to be developed to combat the stress under future conditions.

\section{Tidal non-saline ecosystem}

Wet season rice in about 0.8 million ha in the Barishal agriculture region is frequently affected by freshwater tidal submergence. Therefore, farmers of the region cultivate lower yield potential local Aman rice cultivars, as the cultivars are tidal submergence tolerant due to taller plant height and lodging resistance due to strong stem. Besides, the photoperiod-sensitive local cultivars have the potential to produce good yield even in late planting conditions. Moreover, the photoperiod period sensitive and late planting suitable cultivar such as BR23 is also popular Aman variety in the region. However, recently released BRRI cultivars such as BRRI dhan76 and BRRI dhan77 have the potential to produce 1-2 $\mathrm{t} \mathrm{ha}^{-1}$ yield advantage compared to locally popular local and modern cultivars, including BR23 in the tidal submergence region. Besides, the cultivars are suitable for transplanting in the fields with stagnant water due to taller seedling and plant height and lodging resistant stem. Therefore, large-scale adoption of the cultivars in the tidal submergence region is the potential option to contribute to meeting SDGs.

\section{Haor ecosystem}

The haor ecosystem covers an area of around 8600 sq. $\mathrm{km}$ in the upper Meghna river basin in northeast Bangladesh. About 0.80 million ha of land are suitable for rice cultivation in the haor ecosystem. The area mostly remains fallow in the wet season due to $0.5-4.0$ meters depth of

Table 6. Extrapolated rice production through adoption of resilient cultivars in the drought ecosystem of Bangladesh.

\begin{tabular}{lccccc}
\hline Item & $\begin{array}{c}\text { Base year } \\
(2015)\end{array}$ & 2020 & 2030 & 2040 & 2050 \\
\hline Rice area increase (M ha) compared to base year & 0.21 & 0.63 & 0.84 & 0.84 \\
$(20)$ & $(15)$ & $\begin{array}{c}(20) \\
(15)\end{array}$ & 2.63 & 2.688 \\
Rice production increase (MT) compared to base year & 0.525 & 1.764 & 2.520 \\
Projected yield increases over base year $\left(\mathrm{t} \mathrm{ha}^{-1}\right)$ & $(1.50)$ & $(4.50)$ & $(6.00)$ & $(6.00)$ & $(4.50)$ \\
\hline
\end{tabular}

Note: The advantage of better irrigation management practice was considered in extrapolating Aus and T. Aman yield. Value in the parenthesis is the percentage computed based on the year 2015. 
water for 3-5 months. Therefore, Boro rice is mainly cultivated in the haor region in the dry season. The contribution of the rice is $5.3 \mathrm{MT}$ $\mathrm{yr}^{-1}$, which is about $16 \%$ of total Boro rice production in the country (BBS, 2019). However, the performance of the Boro rice in the region is affected by floods because of heavy rainfall in the early wet season (April to mid-May) and flows of upstream rivers and mountainous in every 3-4 years interval and damaged the crops substantially. The flash flood is a threat to the food security and livelihood of people in the region. The likelihood of affected by early flash floods is very high for the delay transplanting rice. However, the early transplanting rice suffers from spikelet sterility due to low temperature at the reproductive phase. Therefore, the development of higher yield potential short duration and cold-tolerant (at reproductive phase) rice cultivars are required to overcome both the constraints.

Besides, the area is mostly remained fallow in the wet season due to the unavailability of rice cultivars suitable for growing in the deepwater ecosystem, some of the areas are used for cropping local cultivars of Deepwater Rice (DWR) in the wet season. The taller plant height $(>140 \mathrm{~cm}$ ) local cultivars survive in the deepwater due to higher elongation capacity. Some of the local cultivars have the potential to elongate up to $5-8 \mathrm{~cm} \mathrm{~d}^{-1}$ for 7-10 days at the vegetative stage. The local cultivars are established about a month earlier in the deep-water ecosystem to improve their survivability. It can be noted that BRRI dhan91 has the potential to give over $3 \mathrm{t} \mathrm{ha-1}$ yield in the Deep-Water Rice Ecosystem (DWRE). Therefore, the development of high yielding varieties for mediumdeep water condition, pureline selection of existing elongating DWR for deep water environment and large-scale dissemination of the cultivars in the ecosystem may contribute to achieving SDGs.

\section{Rainfed lowland ecosystem}

Rainfed lowland ecosystem is the major ricegrowing area of Bangladesh. The performance of rice in the ecosystem depends on various conditions including amount, time, and length of rainfall, depth and duration of stagnant water, frequency and time of floods, soil type, and topography. This environment is sub-classified as (i) favourable rainfed, (ii) slightly droughtprone, (iii) slightly submergence prone, and (iv) medium-deep submergence prone.

The favourable rainfed ecosystem is sometimes affected by drought at the reproductive phase due to the early withdrawal of post-monsoon rain. However, BRRI dhan66 and BRRI dhan71 have the potential to give per hectare 4.5-5.5 $\mathrm{t} \mathrm{ha}^{-1}$ yield in the areas subject to supplementary irrigation application.

The duration of the rainy season is short in the slightly drought-prone ecosystem (whole Barind areas and Rangpur, Lalmonirhat, Nilphamari, and Kurigram district). As result, wet season rice in the sub-ecosystem is sometimes affected by moderate to extreme drought stress. Therefore, photoperiod insensitive drought escaping and drought tolerant cultivars such as BRRI dhan56 and BRRI dhan57 are the potential cultivars to give 4.0$4.5 \mathrm{t} \mathrm{ha}^{-1}$ yield in the region.

The duration of submergence persists from 2 to 3 weeks in the slightly submergenceprone sub-ecosystem. The wet season in the sub-ecosystem is prolonged and occurred heavy rain until the reproductive phase of $\mathrm{T}$. Aman rice. The moderate to strong photoperiod sensitive varieties such as BRRI dhan51, BRRI dhan52, and BRRI dhan79 are the potential varieties to give a good harvest in the area.

The duration of submergence persists from 3 to 4 months in the deep submergence prone sub-ecosystem. The photoperiod sensitive and submergence tolerant cultivars such 
as BRRI dhan91 have the potential to give a good harvest in the ecosystem.

BR10, BR11, BR25, BRRI dhan30, BRRI dhan32, BRRI dhan46, BRRI dhan49, BRRI dhan54, BRRI dhan72, BRRI dhan87, BRRI dhan93, BRRI dhan94, and BRRI dhan95 are suitable for cropping in the favorable rainfed condition. Besides, BRRI dhan56, BRRI dhan57, BRRI dhan66, and BRRI dhan71 are suitable for growing in the slightly drought-prone ecosystem. Moreover, BRRI dhan51, BRRI dhan52, and BRRI dhan79 are the potential varieties to give good harvest at a slightly submergenceprone ecosystem. Finally, BR22, BR23, BRRI dhan34, and BRRI dhan54 are the potential to give good harvest at late planting conditions after drainage out the flood water and BRRI dhan91 is suitable for cropping in the mediumdeep condition.

The performance of rainfed rice in the area is frequently affected by submergence and drought and other abiotic stresses. As a result, the livelihoods of millions of farmers have been affected adversely. However, adoption of the above-mentioned cultivars and improving management may contribute to increasing rice production for achieving SDGs.

\section{Upland ecosystem}

Upland or dryland rice is grown in rainfed conditions. The rainwater was drained out easily and quickly from the surface of the upland ecosystem. The broadcast rice is cultivated under Jhum culture on the slope of the mountain in the upland ecosystem. The photoperiod insensitive, deep-rooted, and to some extent drought tolerantlocal cultivars are mainly cultivated in the ecosystem. The performance of low yield potential local cultivars in the nutrient-deficient soil and stress ecosystem (moisture stress, heat) is quite low. The severe pest infestation, including weeds and application of imbalance fertilizer dose, and poor agronomic practice, also affected the performance of rice in the ecosystem. The extension supports for dissemination of higher yield potential drought-tolerant rice cultivars (such as BRRIdhan42, BRRI dhan43, BRRI dhan65, and BRRI dhan83) and improving current agronomic practice may contribute to increasing rice production for food security in the upland ecosystem. Besides, research should strengthen for developing (i) higher yield potential rice cultivars introducing preferred traits and (ii) further improved crop management practices for the severe stressprone and nutrient deficient ecosystem.

\section{Charland ecosystem}

Chars are the lands that appear as islands on the bank of rivers and the Bay of Bengal due to the dynamics of erosion and accretion in Bangladesh. The active floodplain and non-saline charland soils occur mainly in Kurigram, Lalmonirhat, Sirajganj, Pabna, Rajshahi, Jamalpur, Manikganj, Faridpur, Kushtia, Shariatpur, Madaripur, and Chandpur. Bangladesh has approximately 0.83 million hectares of charland, of which approximately 0.52-0.79 million are cultivable (BARI, 2016). Based on location, charland are of two types-island Chars and attached chars. Island chars are distributed sporadically in the main channel of the rivers and attached chars, which eventually become an integral part of the mainland. Chars' cultivated soils are mainly sandy loam to silty loam, reacting slightly acidic to slightly alkaline, and deficient in nutrients and organic matter. The charland farmers typically cultivated local crop varieties adopting indigenous crop production practices. As a result, crop yield is extremely poor in charland areas. Some problems are associated with lower crop yields at char areas of Bangladesh but drought and scarcity of irrigation facility could hinder profitable cultivation. Introduction of short duration and drought-tolerant modern rice varieties along with improved management practices and different intercropping systems should be the potential for an increase in production and thereby 
improving the livelihood of the marginal farmers in the charland of Bangladesh.

\section{Low temperature stress (Cold stress)}

The daily mean temperature drops below 20 ${ }^{\circ} \mathrm{C}$ is the potential to make different levels of cold injury in rice crops, depending on growth stages. Common cold injuries include failure to germinate, delayed seedling emergence, stunting, and vegetative leaf discoloration; panicle tip degeneration, incomplete panicle exertion, delayed flowering, high spikelet sterility, and irregular reproductivephase maturity (Yoshida, 1981). The growth and development of Boro rice in Bangladesh are affected by cold injury despite the short winter season in Bangladesh. The mild to severe cold waves $\left(<10-12{ }^{\circ} \mathrm{C}\right)$ during midDecember to late-January frequently affected seedling growth in nursery, vegetative growth after transplanting, and sometimes delayed the transplanting, consequently affected on the performance of the rice crop in the north-western region of the country. Besides, the early transplanting medium growth-duration Boro cultivars (e.g., BRRI dhan28) in the Haor ecosystem are sometimes affected by cold injury $\left(<18{ }^{\circ} \mathrm{C}\right)$ at the reproductive phase during mid to late February, consequently increased rice grain sterility. However, the rice crop could be escaped from unexpected yield loss subject to shifted delay transplanting of the medium-growthduration rice cultivars after mid-November. Besides, BRRI dhan67 and BRRI dhan69 were identified as moderately cold tolerant at the reproductive phase so that adoption of the varieties in the Haor ecosystem might be reduced unexpected yield loss. Moreover, BRRI has been working on two advanced lines (such as TP16199 and TP7594) for releasing as the variety for the Haor region.

\section{High temperature stress (Heat stress)}

The heat stress affects the performance of rice in the tropical and subtropical regions. Although, the typical heat episodes persist for a short period. However, an overlap of heat episodes and critical flowering stage pose a serious threat to spikelet fertility, consequently occur a yield penalty (Jagadish et al., 2007). The persistence of the temperature over $35^{\circ} \mathrm{C}$ for two hours at the flowering stage affects anther dehiscence, pollination, and pollen germination, caused rice grain sterility, consequently reduced yield. It can be noted that some exotic Aus rice cultivars such as N22, Kachalath, and Dularis the potential to maintain high spikelet fertility under up to $35-38{ }^{\circ} \mathrm{C}$ at the flowering stage.

The heat stress at the susceptible reproductive phase of the rice crop is correlated with water deficit periods in some areas of Bangladesh. The drought and heat combinedly aggravated the moisture stress at the reproductive phase of the rice crop (Wassmann et al., 2009). It was projected that water-deficit stress at rice cropping season might be doubled under future conditions due to decreased precipitation and rise in the temperature in the subtropical climatic region(IPCC, 2007; Wassmann et al., 2009). Besides, global mean warming and heat stress is likely to rise steadily across the $21^{\text {st }}$ century (IPCC, 2013). As a result, the likelihood of affected by spikelet sterility due to moisture stress is a potential threat for rice cropping in the tropical and subtropical regions under future conditions.

Currently, the long duration Boro cultivar namely BRRI dhan 29 has been encountering sterility problems due to rise temperature over threshold level both for day $\left(>35^{\circ} \mathrm{C}\right)$ and night $28-30{ }^{\circ} \mathrm{C}$ at the flowering stage in late March to April (Shelley et al., 2016). Similarly, the medium duration ( $\sim 140$ days) variety like BRRI dhan 28 has also been experiencing heat-induced spikelet sterility when delayed transplanting after potato harvest or grown in the Aus season. The short duration T. Aman varieties (BRRI dhan33, BRRI dhan39, BRRI dhan75) are vulnerable to heat stress poses driven spikelet sterility due to rising temperature at the flowering stage of the cultivars (September to October). 
The shifting of transplanting time of Boro rice early and delaying the short duration $\mathrm{T}$. Aman rice varieties might help to escape encountering over threshold temperature at the flowering stage. Besides, the development and dissemination of heat-tolerant rice varieties is a viable strategy to overcome the rising temperature and heat stress-driven challenges (Challinoret al., 2014). Moreover, the adverse impact of heat stress might be escaped through developing early morning flowering potential rice varieties. BRRI research on the development of heat-tolerant rice varieties through introgression heat-tolerant trait on BRRI dhan 28 and BRRI dhan29 at yield is at evaluation stage. Besides, BRRI is expected to develop heat tolerance and early morning flowering (EMF) potential cultivars by the next 2-3 years.

Extrapolated rice area and production in Bangladesh

Table 7 presents extrapolated rice production increase through the adoption of stress-tolerant rice cultivars in the salinity, submergence, and drought ecosystems in Bangladesh. There is potential to add about 13.89 MT of rice to the national rice basket in 2050 subject to introduce stress-tolerant rice cultivars in $75 \%$ of total area of salinity, submergence, and drought ecosystems in the country.

Actions for achieving rice production increasing goal in the unfavourable ecosystems of Bangladesh

Table 8 lists required research and upscaling activities for increasing rice area and production in unfavourable and stress environments. Firstly, the gravity of stress of each ecosystem should be characterized for developing stress-resilient cultivars and component technologies for the unfavourable ecosystems. The ecosystem characterization activity will have been continued across future conditions. It is due to the frequency and intensity of the stresses have been increasing over time. The research for developing stress-tolerant rice cultivars and management practices have to be continued for combating the adverse consequences of biotic and abiotic stresses on the performance of rice crops. Besides, policy supports are required for developing infrastructure, in particular fresh-water reservoirs and drainage canals for reducing water stagnation. The policy supports are also needed for strengthening research and extension activities for developing and disseminating the technologies to the respective unfavourable ecosystem.

Finally, varietal demonstration will have to be set up at farmers' fields in collaborations with the Department of Agricultural Extension (DAE) during the first half of each decade. The extension linkage will be needed to develop for setting large-scale and mass demonstrations on the most stress-resilient rice cultivars and stress management technologies at farmers' fields in the stress ecosystems across the country during the second half of each future decade.

Table 7. Extrapolated rice production through the adoption of stress-tolerant cultivars in the salinity, submergence, and drought ecosystems in Bangladesh.

\begin{tabular}{|c|c|c|c|c|c|}
\hline Item & $\begin{array}{l}\text { Base year } \\
\quad(2015)\end{array}$ & 2020 & 2030 & 2040 & 2050 \\
\hline Rice area increase (M ha) compared to base year & -- & $0.97(36)$ & $1.26(50)$ & $1.26(50)$ & $0.91(35)$ \\
\hline Rice production increase (MT) compared to base year & -- & $2.63(10)$ & $3.80(14)$ & $4.15(14)$ & $3.31(10)$ \\
\hline $\begin{array}{l}\text { Projected phasic production requirement over base } \\
\text { year }(\mathrm{MT})^{*}\end{array}$ & 35.30 & 37.00 & 40.40 & 43.80 & 47.20 \\
\hline
\end{tabular}

Note: Value in the parentheses is the percentage computed based on the year 2015. *Source: Kabir et al. 2020 
Table 8. Research and extension activities for enhancing rice production in unfavourable ecosystems and stress environments under future conditions in Bangladesh.

\begin{tabular}{|c|c|c|c|c|c|c|c|}
\hline \multirow{2}{*}{$\begin{array}{l}\text { Unfavourable } \\
\text { ecosystem }\end{array}$} & \multirow{2}{*}{$\begin{array}{l}\text { Action required to improve the } \\
\text { prevailing conditions for } \\
\text { increased rice production }\end{array}$} & \multicolumn{2}{|c|}{ 2021-2030 } & \multicolumn{2}{|c|}{ 2031-2040 } & \multicolumn{2}{|c|}{ 2041-2050 } \\
\hline & & $2021-25$ & $2026-30$ & 2031-35 & $2036-40$ & $2041-45$ & $\begin{array}{l}2046 \\
2050\end{array}$ \\
\hline \multirow{6}{*}{ Salinity } & $\begin{array}{l}\text { - Characterization of ecosystem } \\
\text { (Distribution and severity of soil } \\
\text { and water salinity) }\end{array}$ & Completing & & $\begin{array}{l}\text { Updating } \\
\text { info }\end{array}$ & & $\begin{array}{l}\text { Updating } \\
\text { info }\end{array}$ & \\
\hline & \begin{tabular}{|l} 
Variety \\
(Salinity+drought+heat+stagnat \\
ion tolerant with short duration) \\
\end{tabular} & \multicolumn{6}{|c|}{ Continue improving } \\
\hline & $\begin{array}{l}\text { Water management (Source of } \\
\text { sweet water, rainwater harvest } \\
\text { and management of canals) } \\
\end{array}$ & \multicolumn{6}{|c|}{ Continue improving } \\
\hline & $\begin{array}{l}\text { - Crop management (Ridge and } \\
\text { furrow planting, mulching for } \\
\text { non-rice crop) }\end{array}$ & \multicolumn{6}{|c|}{ Continue improving } \\
\hline & $\begin{array}{l}\text { Soil health management } \\
\text { (Addition of organic matter, } \\
\text { balanced fertilization, gypsum } \\
\text { and potash application) }\end{array}$ & \multicolumn{6}{|c|}{ Continue improving } \\
\hline & $\begin{array}{l}\text { Policy development (Polder } \\
\text { management, area demarcation } \\
\text { for salt and shrimp farming) }\end{array}$ & \multicolumn{6}{|c|}{ Continue improving } \\
\hline \multirow{4}{*}{ Submergence } & $\begin{array}{l}\text { Characterization of ecosystem } \\
\text { (Flooding depth, duration, } \\
\text { turbidity, turbulence, dissolve } \\
\text { oxygen concentration) }\end{array}$ & Completing & & $\begin{array}{l}\text { Updating } \\
\text { info }\end{array}$ & & $\begin{array}{l}\text { Updating } \\
\text { info }\end{array}$ & \\
\hline & \begin{tabular}{|l} 
- Variety (Multiple flood tolerant, \\
drought and stagnation tolerant \\
including photosensitivity)
\end{tabular} & \multicolumn{6}{|c|}{ Continue improving } \\
\hline & $\begin{array}{l}\text { Specific fertilizer management } \\
\text { for quick recovery after de- } \\
\text { submergence }\end{array}$ & \multicolumn{6}{|c|}{ Continue improving } \\
\hline & $\begin{array}{l}\text { - Location specific variety } \\
\text { adoption and management } \\
\text { practices }\end{array}$ & \multicolumn{6}{|c|}{ Continue improving } \\
\hline \multirow{4}{*}{ Drought } & $\begin{array}{l}\text { - Characterization of ecosystem } \\
\text { (Occurrence, severity and } \\
\text { duration, sources of irrigation, } \\
\text { rainwater harvest) }\end{array}$ & Completing & & $\begin{array}{l}\text { Updating } \\
\text { info }\end{array}$ & & $\begin{array}{l}\text { Updating } \\
\text { info }\end{array}$ & \\
\hline & $\begin{array}{l}\text { Variety (Highly drought } \\
\text { tolerant, heat tolerant and short } \\
\text { duration) }\end{array}$ & \multicolumn{6}{|c|}{ Continue improving } \\
\hline & $\begin{array}{l}\text { Adjusting planting time to } \\
\text { escape drought period }\end{array}$ & \multicolumn{6}{|c|}{ Continue improving } \\
\hline & $\begin{array}{l}\text { Location specific variety } \\
\text { adoption and management } \\
\text { practices }\end{array}$ & \multicolumn{6}{|c|}{ Continue improving } \\
\hline
\end{tabular}


Table 8. Continued.

\begin{tabular}{|c|c|c|c|c|c|c|c|}
\hline \multirow{2}{*}{$\begin{array}{l}\text { Unfavourable } \\
\text { ecosystem }\end{array}$} & \multirow{2}{*}{$\begin{array}{l}\text { Action required to improve the } \\
\text { prevailing conditions for } \\
\text { increased rice production }\end{array}$} & \multicolumn{2}{|c|}{ 2021-2030 } & \multicolumn{2}{|c|}{$2031-2040$} & \multicolumn{2}{|c|}{$2041-2050$} \\
\hline & & $2021-25$ & $2026-30$ & $2031-35$ & $2036-40$ & $2041-45$ & 2046-2050 \\
\hline \multirow{2}{*}{ Haor } & $\begin{array}{l}\text { - Characterization of ecosystem } \\
\text { (Depth of water and suitability } \\
\text { DW, FR and enhanced Boro } \\
\text { cultivation) }\end{array}$ & Completing & & $\begin{array}{l}\text { Updating } \\
\text { info }\end{array}$ & & $\begin{array}{l}\text { Updating } \\
\text { info }\end{array}$ & \\
\hline & $\begin{array}{l}\text { - Crop management (Fertilizer, } \\
\text { weed, pest, rat management } \\
\text { and harvesting issues) }\end{array}$ & \multicolumn{6}{|c|}{ Continue improving } \\
\hline \multirow{3}{*}{$\begin{array}{l}\text { Tidal } \\
\text { Submergence }\end{array}$} & $\begin{array}{l}\text { - Characterization of ecosystem } \\
\text { (Characterizing tidal waves by } \\
\text { depth, turbulence and quality } \\
\text { of water) }\end{array}$ & Completing & & $\begin{array}{l}\text { Updating } \\
\text { info }\end{array}$ & & $\begin{array}{l}\text { Updating } \\
\text { info }\end{array}$ & \\
\hline & $\begin{array}{l}\text { - Variety (Taller and } \\
\text { flexible/tender stem, strong } \\
\text { photosensitivity, glossy leaves) }\end{array}$ & \multicolumn{6}{|c|}{ Continue improving } \\
\hline & $\begin{array}{l}\text { - Efficient fertilizer management } \\
\text { under tidal water condition }\end{array}$ & \multicolumn{6}{|c|}{ Continue improving } \\
\hline \multirow{3}{*}{$\begin{array}{l}\text { Rainfed Low } \\
\text { Land }\end{array}$} & $\begin{array}{l}\text { Variety (Submergence, drought, } \\
\text { heat and stagnation tolerance } \\
\text { including strong photosensitivity) }\end{array}$ & \multicolumn{6}{|c|}{ Continue improving } \\
\hline & $\begin{array}{l}\text { - Crop management (Double } \\
\text { transplanting, weed and } \\
\text { fertilizer management) }\end{array}$ & \multicolumn{6}{|c|}{ Continue improving } \\
\hline & $\begin{array}{l}\text { - Water management (Special } \\
\text { water management like } \\
\text { supplemental irrigation) }\end{array}$ & \multicolumn{6}{|c|}{ Continue improving } \\
\hline \multirow[b]{2}{*}{ Upland } & $\begin{array}{l}\text { - Characterization of ecosystem } \\
\text { (Plough pan/hardpan, } \\
\text { suitability for water saving rice) }\end{array}$ & Completing & & $\begin{array}{l}\text { Updating } \\
\text { info }\end{array}$ & & $\begin{array}{l}\text { Updating } \\
\text { info }\end{array}$ & \\
\hline & $\begin{array}{l}\text { - Variety (Deep root system, } \\
\text { water saving, drought and heat } \\
\text { tolerant, short duration, and } \\
\text { perennial type) }\end{array}$ & \multicolumn{6}{|c|}{ Continue improving } \\
\hline
\end{tabular}


Table 8. Continued.

\begin{tabular}{|c|c|c|c|c|c|c|c|}
\hline \multirow{2}{*}{$\begin{array}{l}\text { Unfavourable } \\
\text { ecosystem }\end{array}$} & \multirow{2}{*}{$\begin{array}{l}\text { Action required to improve the } \\
\text { prevailing conditions for } \\
\text { increased rice production }\end{array}$} & \multicolumn{2}{|c|}{$2021-2030$} & \multicolumn{2}{|c|}{$2031-2040$} & \multicolumn{2}{|c|}{$2041-2050$} \\
\hline & & $2021-25$ & $2026-30$ & $2031-35$ & $2036-40$ & $2041-45$ & 2046-2050 \\
\hline & $\begin{array}{l}\text { - Crop management (Water } \\
\text { saving technique-mulching, } \\
\text { weed and pest management) }\end{array}$ & \multicolumn{6}{|c|}{ Continue improving } \\
\hline \multirow{3}{*}{ Charland } & $\begin{array}{l}\text { - Characterization of ecosystem } \\
\text { (Suitability of rice + non-rice } \\
\text { crop cultivation, source of } \\
\text { irrigation water) }\end{array}$ & Completing & & $\begin{array}{l}\text { Updating } \\
\text { info }\end{array}$ & & $\begin{array}{l}\text { Updating } \\
\text { info }\end{array}$ & \\
\hline & $\begin{array}{l}\text { - Variety (Short duration, } \\
\text { drought and heat tolerant) }\end{array}$ & \multicolumn{6}{|c|}{ Continue improving } \\
\hline & $\begin{array}{l}\text { - Crop management } \\
\text { (Improvement of soil health } \\
\text { and productivity) }\end{array}$ & \multicolumn{6}{|c|}{ Continue improving } \\
\hline \multirow{2}{*}{$\begin{array}{l}\text { Low } \\
\text { temperature }\end{array}$} & $\begin{array}{l}\text { - Variety (Low temp tolerant for } \\
\text { seedling \& reproductive stage) }\end{array}$ & \multicolumn{6}{|c|}{ Continue improving } \\
\hline & $\begin{array}{l}\text { - Adjustment of planting to } \\
\text { escape low temperature effect } \\
\text { in combination with yield } \\
\text { target }\end{array}$ & \multicolumn{6}{|c|}{ Continue improving } \\
\hline \multirow[t]{2}{*}{$\begin{array}{l}\text { High } \\
\text { temperature }\end{array}$} & $\begin{array}{l}\text { - Variety (Drought and heat } \\
\text { tolerant with Early Morning } \\
\text { Flowering to escape heat } \\
\text { period during flowering) }\end{array}$ & \multicolumn{6}{|c|}{ Continue improving } \\
\hline & $\begin{array}{l}\text { - Efficient water management to } \\
\text { mitigate heat and drought } \\
\text { effects }\end{array}$ & \multicolumn{6}{|c|}{ Continue improving } \\
\hline \multirow{3}{*}{$\begin{array}{l}\text { For all } \\
\text { ecosystems }\end{array}$} & $\begin{array}{l}\text { - Up-scaling activities: } \\
\text {--Site characterization } \\
\text {-- Set demonstration }\end{array}$ & & & & & & \\
\hline & $\begin{array}{l}\text { - Set large-scale/mass } \\
\text { demonstration }\end{array}$ & & & & & & \\
\hline & - Developed extension linkage & & & & & & \\
\hline
\end{tabular}

'info' denoted for information 


\section{CONCLUSION}

BR23, BRRI dhan40, BRRI dhan41, BRRI dhan47, BRRI dhan53, BRRI dhan54, BRRI dhan61, BRRI dhan67, BRRI dhan73, BRRI dhan78, BRRI dhan97, BRRI dhan99, BINA dhan 8 and BINA dhan 10 are resilient to salinity. Besides, BRRI dhan56, BRRI dhan57, BRRI dhan66, BRRI dhan71, and BRRI dhan83 are resilient to drought, and BRRI dhan51, BRRI dhan52, BRRI dhan79, BINA dhan11, and BINA dhan12 are tolerant to submergence. The BR18, BRRI dhan36, BRRI dhan67, and BRRI dhan69 are to some-extent cold resilient. About 1.26 MT, 3.45 MT, and 9.18 MT rice production may increase subject to improve agronomic practice and adoption of stresstolerant rice cultivars in the $0.37 \mathrm{Mha}, 1.08$ Mha, 2.94 Mha of the salinity, submergence, and drought ecosystems, respectively. Resulting from that 13.89 MT of rice will be added to the national rice basket in 2050. The policy supports are needed for rapid dissemination of the stress-tolerant cultivars in unfavourable ecosystems and development of more stresstolerant rice cultivars and management practices for future conditions.

\section{RECOMMENDATIONS}

- The extension supports need to be strengthened for disseminating currently available specific abiotic and biotic stress-tolerant rice cultivars to the respective stress-prone ecosystems to enhance rice production in the country to achieve SDGs.

- Farmers' access to higher yield potential and further stress-tolerant (multi stress-tolerant) cultivars for saline, submergence, and drought-prone ecosystem needs to be developed and disseminated to achieve the SDGs and for meeting the increased demand of the growing population by 2050 .

- Climate-smart agronomic and pest management technologies in the saline, submergence, drought, and cold-prone ecosys- tems need to be developed and disseminated.

- Varieties with higher yield potential and up to four weeks and recurrent submergence tolerance at the vegetative phase, and drought at the reproductive phase need to be developed and disseminated to the submergence ecosystem to reduce the unexpected yield loss. Besides, agronomic management needs to be improved to achieve the expected yield of the ecosystem.

- Farmer's access to fresh-water for irrigation in the saline and non-saline ecosystem needs to be improved through re-excavation of canals and developing farm-friendly canal water management for achieving SDGs.

- Rice varieties and agronomic practices need to be developed for flash flood submergence-prone ecosystem considering the gravity of floods, including water depth and quality (muddy or clear), frequency of occurrence, and length.

- The over-extraction of underground waterneeds to be reduced through capitalizing the rainwater by adjusting cropping seasons and storing the rainwater in the reservoirs in the drought-prone ecosystem. Besides, the adoption of improved irrigation water management for cropping might reduce the excessive stress of groundwater aquifer.

- For the upland environment, higher yield potential and drought-tolerant Aus rice cultivars need to be developed for enhancing productivity and farm income. The policy supports are needed for enhancing rice area and productivity through improving nutrient management and agronomic practices in the ecosystem.

- For Charland, rice variety needs to be identified and developed based on soil types, drought severity, and irrigation water 
availability to enhance rice production in the ecosystem.

- The development of higher yield potential short duration and cold-tolerant (at reproductive phase) rice cultivars are required to overcome flash floods and cold stress in the Haor ecosystem. Besides, the development of an early-warning system about flash floods at the reproductive phase of Boro rice in the ecosystem might reduce unexpected crop loss. Similarly, rice cultivar tolerance to cold at seedling and reproductive phase need to be developed for the north-east and west region of the country. Shifting transplanting time of Boro rice to early and delaying the short duration T. Aman rice varieties might help to reduce unexpected yield plenty due to heat stress. Besides, the development and dissemination of early morning flowering potential rice varieties might also reduce unexpected yield loss across seasons and ecosystems.

\section{ACKNOWLEDGEMENTS}

The authors wish to thank anonymous reviewers for their suggestions, which significantly improved this article.

\section{AUTHORS' CONTRIBUTION}

MSR generated idea; AKMSI, MARS and MAAM coordinated the research; MSR and $\mathrm{MMH}$ developed methodology; MSR, MMH, MJK, MUS and MSK provided scientific insights; MSR gathered data, carried out analysis and synthesis; MSR did the writings for all versions of the manuscript; MJK, MARS, MAAM and MUS performed critical review and editing; All authors read and approved the final manuscript.

\section{DECLARATION OF INTERESTS}

A version of the paper was published in a book 'Doubling Rice Productivity in Bangladesh' in 2020 by the Bangladesh Rice Research Institute (BRRI), Gazipur 1701, Bangladesh to commemorate BRRI's 50th anniversary. The Bangladesh Rice Journal has prior knowledge of the book publication and does not see any conflict of interest.

\section{REFERENCES}

Ahmed, A U and M M Q Mirza. 2000. Review of causes and dimensions of floods with particular reference to Flood 1998: National Perspectives. In: Perspectives on Flood, Q K Ahmed, A K A Chowdhury, S H Imam, M Sarker (Eds.), Dhaka University Press Limited, Dhaka, Bangladesh, 65-89.

Alam, S M N, H Demaine and M J Phillips. 2002. Land use diversity in south western coastal areas of Bangladesh. The Land, 6 (3):173-184.

Bairagi, S and E Bari. 2015. Economic cost of natural calamities in Bangladesh agriculture: A Bayesian analysis. Unpublished Working Paper, Center for Policy Dialogue (CPD), Dhaka.

Bairagi, S, H Bhandari, S K Das and S Mohanty. 2018. Impact of Submergence-Tolerant Rice Varieties on Small holders' Income and Expenditure: Farm-Level Evidence from Bangladesh. Agricultural and Applied Economics Association Annual Meeting, Washington DC, August 5- 7, 2018.

Bala, B K and M A Hossain. 2010. Food security and ecological footprint of coastal zone of Bangladesh. Environment, Development and Sustainability,12 (4): 531-545.

BARI (Bangladesh Agricultural Research Institute). 2016.Unfavourable ecosystem: Crop production under charland ecosystem. Unfavourable ecosystem publication no. 4, Agronomy Division, BARI, Joydevpur, Gazipur.

BBS (Bangladesh Bureau of Statistics). 2018. Statistical Year Book of Bangladesh 2018, Bangladesh Bureau of Statistics (BBS), Ministry of Planning, Government of the People's Republic of Bangladesh, Dhaka, Bangladesh

BBS (Bangladesh Bureau of Statistics).2019. Yearbook of agricultural statistics of Bangladesh 2019, Bangladesh Bureau of Statistics (BBS), Ministry of Planning, Government of the People's Republic of Bangladesh, Dhaka, Bangladesh.

Bhumbla, D R and I P Abrol. 1978. Saline and sodic soils. In: Soils and Rice. Proceedings of the IRRI Symposium on Soils and Rice. International Rice Research Institute, Manila, Philippines, 719-738.

BRRI (Bangladesh Rice Research Institute). 2013.Annual Research Review Workshop 2013, Plant Breeding Division2012-2013, Bangladesh Rice Research Institute (BRRI), Gazipur-1701, Bangladesh. 
BRRI (Bangladesh Rice Research Institute). 2017. Annual Research Review Workshop 2017, Plant Breeding Division 2015-2016, Bangladesh Rice Research Institute (BRRI), Gazipur-1701, Bangladesh.

BRRI (Bangladesh Rice Research Institute). 2018. Annual Research Review Workshop 2018, Plant Breeding Division 2016-2017, Bangladesh Rice Research Institute (BRRI), Gazipur-1701, Bangladesh.

Challinor, A, J Watson, D Lobell, S Howden, D Smith and N Chhetri. 2014.A meta-analysis of crop yield under climate change and adaptation.Nat.Clim.Chang., 4:287-291.

Dewan, A M, M Nishigaki and M Komatsu. 2003.Floods in Bangladesh: A comparative hydrological investigation on two catastrophic events. Journal of the Faculty of Environmental Science and Technology, 8 (1): 53-62.

Dewan, TH. 2015. Societal impacts and vulnerability to floods in Bangladesh and Nepal. Weather and Climate Extremes, 7: 36-42.

FAO (Food and Agriculture Organization of the United Nations). 1988. Land Resources Appraisal of Bangladesh for Agricultural Development. Report 2: Agroecological Regions of Bangladesh, Food and Agriculture Organization (FAO), Rome.

Gumma, M K, A Nelson, A Maunahan, P S Thenkabail and S Islam. 2012.Rice cropping patterns in Bangladesh. Rice Today, January-March 2012, IRRI, Philippines.

Ibrahim, M, M A U Zaman, A B M Mostafizur and S M Shahidullah. 2017.Diversity of Crops and Land Use Pattern in Barisal Region. Bangladesh Rice J., 20 (2): 57-72.

Idowu, M K and E A Aduayi. 2007.Sodium-potassium interaction on growth, yield and quality of tomato in ultiso. Journal of Plant Interactions, 2 (4): 263271

IPCC (The Intergovernmental Panel on Climate Change). 2007. Summary for policy makers. In: Climate Change 2007, The Physical Science Basis 9.

IPCC (The Intergovernmental Panel on Climate Change). 2013.Working Group I contribution to the IPCC fifth assessment report on climate change 2013: The physical science basis, summary for policymakers.http://www.climatechange2013.org/image/rep ort/WG1AR5\%20SPM\%20FINAL.pdf.

Jagadish, S V K, P Q Craufurd and T R Wheeler. 2007. High temperature stress and spikelet fertility in rice (Oryza sativa L.). Journal of Experimental Botany, 58: 1627-1635.

Kabir, M S, M U Salam, A K M S Islam, M A R Sarkar, M A A Mamun, M C Rahman, B Nessa, M J Kabir, H B Shozib, M B Hossain, A Chowdhury, M Nasim, K M Iftekharuddaula, M S Hossain, M K A Bhuiyan, B
Karmakar, M S Rahman, M M Haque, M T Khatun, M P Ali, S M H A Rabbi, P L Biswas, E S M H Rashid and N M FRahman. 2020. Doubling rice productivity in Bangladesh: A way to achieving SDG2 and moving forward. Bangladesh Rice Journal, 24 (2): 1-47.

Kabir, M J, K M Iftekharuddaula, T L Aditya and M S Kabir. 2018c. Rice Technological Innovation and Value Chain Development in Bangladesh: Current Status and Future Directions (Chapter-3). In: Rice Technological Innovation and Value Chain Development in South Asia: Current Status and Future Directions, P R Pandey and $\mathrm{H}$ Bhandari (Eds.), SAARC Agriculture Centre, 22-48.

Kabir, M S, M U Salam, A Chowdhury, N M F Rahman, K M Iftekharuddaula, M S Rahman, M H Rashid, S S Dipti, A Islam, M A Latif, A K M S Islam, M M Hossain, B Nessa, T H Ansari, M A Ali and J K Biswas. 2015. Rice Vision for Bangladesh: 2050 and Beyond. Bangladesh, Rice J., 19 (2): 1-18.

Kabir, M J, R Cramb, M Alauddin and C Roth. 2016. Farming adaptation to environmental change in coastal Bangladesh: shrimp culture versus crop diversification. Environment, Development and Sustainability, 18 (4): 1195-1216.

Kabir, M J, R Cramb, M Alauddin, C Rothand S Crimp. 2017a. Farmers' Perceptions of and Responses to Environmental Change in Southwest Coastal Bangladesh.Asia Pacific Viewpoint, 58 (3): 362-378.

Kabir, M J, R Cramb, D S Gaydon and C Roth. 2017b. Bioeconomic evaluation of cropping systems for saline coastal Bangladesh: ii. Economic viability under historical and future environments.Agricultural Systems, 155: 103-115.

Kabir, M J, R Cramb, D S Gaydon and C Roth. 2018a. Bioeconomic evaluation of cropping systems for saline coastal Bangladesh: III Benefits of adaptation under future conditions.Agricultural Systems, 161: 28-41.

Kabir, M J, M Alauddin and S Crimp. 2017c. Farm-level adaptation to climate change in Western Bangladesh: An analysis of adaptation dynamics, profitability and risks.Land use policy, 64: 212-224.

Kabir, M J, R Cramb, M Alauddin and D S Gaydon. 2019. Farmers' perceptions and management of risk in rice-based farming systems of south-west coastal Bangladesh.Land Use Policy, 86: 177-188.

Kabir, M J, R Cramb, M Alauddin, D S Gaydon and C H Roth. 2020. Farmers' perceptions and management of risk in rice/shrimp farming systems in SouthWest Coastal Bangladesh.Land Use Policy, 95: 104577.

Kabir, M J, D S Gaydon, R Cramb and C H Roth. 2018b. Bio-economic evaluation of cropping systems for saline coastal Bangladesh: I. Biophysical simulation 
in historical and future environments. Agricultural Systems, 162: 107-122.

Kreft, S, D Eckstein and I Melchior. 2016. Global Climate Risk Index 2017: Who suffers most from extreme weather events? Weather-related Loss Events in 2015 and 1996 to 2015. Briefing Paper, German watch e.V., Bonn.

Maas, E V and G J Hoffman. 1976. Crop salt tolerance: evaluation of existing data.In: Managing Saline Water for Irrigation (184-98), H EDregre (Eds.). Texas Tech University, Lubbock, USA.

Maas, E V and G J Hoffman. 1977. Crop salt tolerancecurrent assessment. Journal of the irrigation and drainage division, 103 (2): 115-134.

Majumder, S. 2013. The economics of early response and resilience: Bangladesh country study. Available at https://assets.publishing.service.gov.uk/media/57 a08a40e5274a31e00004e0/61114_Bangladesh_ Background_Report.pdf.

Maniruzzaman, M, M J Kabir, M B Hossain, M S Yesmin, A B M Mostafizur and P K Kundu. 2020. Final Report 2020, Cropping systems intensification in the saltaffected coastal zones of Bangladesh and West Bengal, India, Canberra, Australia.

Munns, R and M Tester. 2008. Mechanisms of salinity tolerance. Annual Review of Plant Biology, 59: 651-681.

Rahman, R B and J Zhang. 2016. Flood and drought tolerance in rice: Opposite but may coexist. Food and Energy Security, 5 (2): 76-88.

Rana, R S. 1985: Breeding for salt resistance: concept and strategy. Int. J. Trop. Agric., 3: 236-254.

Sarkar, M A R and H Bhandari. 2018. Adoption status and performance of stress tolerant rice cultivars. In: Seminar at International Rice Research Institute (IRRI), 1 August 2018, IRRI, Dhaka, Bangladesh.

Rashid, M H, B J Shirazy, M Ibrahim and S M Shahidullah. 2017. Cropping Systems and their Diversity in Khulna Region. Bangladesh Rice J., 20 (2): 203-216.

Rehman, M Z, G Murtaza, M F Qayyum, U Saifullah, M Rizwan, S Ali, F Akmaland H Khalid. 2016. Degraded Soils: Origin, Types and Management. In: Soil Science: Agricultural and Environmental Prospectives, Hakeem KR et al. (eds.), Springer International Publishing Switzerland. DOI: 10.1007/978-3-319-34451-5_2
Ruane, A C, D C Major, W H Yu, M Alam, S G Hussain, A S Khan,A Hassan,BMTA Hossain, R Goldberg, RM Horton and C Rosenzweig. 2013. Multi-factor impact analysis of agricultural production in Bangladesh with climate change. Glob. Environ. Chang., 23 (1): 338-350.

Salam, M U, B K Mahalder, H Bhandari, M S Kabir, M A R Sarkar, B Nessa and M A Ali. 2019. Policy directions toward increasing rice productivity-Lessons from Bangladesh.In: Advances in Rice Research for Abiotic Stress Tolerance, M Hasanuzzaman, M Fujita, K Nahar, J K Biswas (Eds.).Woodhead Publishing. DOI: 10.1016/B978-0-12-814332-2.00044-7

Shelley, I J, M T Nosaka, M K Nakata, M S Haqueand Y Inukai. 2016. Rice Cultivation in Bangladesh: Present Scenario, Problems, and Prospects.J. Intl. Cooper. Agric. Dev., 14: 20-29.

SRDI (Soil Resource Development Institute). 2010.Saline Soils of Bangladesh. SFSDP program, Soil Resource Development Institute, Ministry of Agriculture, People's Republic of Bangladesh, Dhaka, Bangladesh.

Thurlow, J, P Dorosh and W Yu. 2012.A stochastic simulation approach to estimating the economic impacts of climate change in Bangladesh.Rev. Dev. Econ., 169 (3) : 412-428.

Uddin, M N. 1993. Rice in Bangladesh. 27th International Symposium on Plant Genetic Resource Management in the Tropics. Tropical Agriculture Research Center (TARC), 31-41.

Warwick, R A. 1975. Drought hazard in the United States: A research assessment: Boulder. University of Colorado, Institute of Behavioral Science, Colorado (Monograph no. NSF/RA/E-75/004, 199 p.).

Wassmann, R, S V K Jagadish, K Sumfleth, H Pathak, G Howell, AIsmail et al. 2009. Regional vulnerability of climate change impacts on Asian rice production and scope for adaptation.Adv.Agron., 102: 99-133.

Wilhite, D A and M H Glantz. 1985. Understanding the Drought Phenomenon: The Role of Definitions. Water International, 10 (3): 111-120.

Yoshida, S. 1981. Fundamentals of Rice Crop Science. International Rice Research Institute: Los Banos, Philippines.

Yu, W, M Alam, A Hassan, A S Khan, A Ruane, C Rosenzweig, D C Major and J Thurlow. 2010. Climate Change Risks and Food Security in Bangladesh, Earthscan publishing, Washington, DC, USA. 